\title{
Industrial and Employment Effect of China-Korea FTA: Negotiation Strategy and Institutional Preparation for Countries Seeking for FTA with China
}

\author{
Joonmo Cho' ${ }^{1}$, Kwangho Woo ${ }^{2}$, Hae-Chun Rhee ${ }^{3}$ \\ ${ }^{1,3}$ Sungkyunkwan University \\ Myeongnyun 3-ga, Jongno-gu, Seoul, Korea \\ e-mail: trustcho@skku.edu,rheehc@skku.edu \\ ${ }^{2}$ HRD Center, Sungkyunkwan University \\ 53 Myeongnyun-dong, 3-ga, Jongno-gu, Seoul, Korea \\ e-mail:wookh1@gmail.com \\ cross $^{\text {ref }}$ http://dx.doi.org/10.5755/j01.ee.24.2.2836
}

China is not only one of the biggest countries, but the second economic giant in the world. For this reason, many countries preparing for a FTA with China, including the EU, express concerns about the domestic industry downfall, in particular, that of the labor-intensive such as agriculture industry. This study empirically assesses the impact of the China-Korea FTA on the industrial competitiveness and labor market of both countries. An econometric analysis was conducted on the impact of the China-Korea FTA, and the Fuzzy-Delphi analysis was performed on a panel of experts in order to complement the quantitative analysis. Further, the Fuzzy Decision-Making method was primarily used in the opinion survey. The method takes into consideration the uncertainties in the judgment of the panel of experts in the Delphi-Survey, which predicts the qualitative effect of the China-Korea FTA. Overall, our results reveal that the China-Korea FTA would have a positive impact on the industrial competitiveness or employment situation of China and Korea. If the Korea-China FTA is concluded, Korea will have the upper hand in the automobile, auto parts, and textile and clothing industries in terms of industrial production. However, there exits an underlying possibility that a production increase may not lead to effective job creation as production facilities may relocate to China where there is a relatively lower labor cost. Industries found to be in a weaker position based on the conclusion of the Korea-China FTA were agriculture, forestry, \& fishery, mining, wooden furniture and processed foods; such industries were found to unlikely see the creation of jobs. This study also suggests negotiation strategies which can ensure a win-win for both parties. Further, it also discusses various institutional improvements for industries or workers impacted by the trade adjustment, which is required to maximize the effect of the China-Korea FTA.

Keywords: China-Korea FTA, Labor Market Impact, Industrial Competitiveness, Delphi, Fuzzy method.

\section{Introduction}

The object of this study is the China-Korea FTA. China accounts for 10 percent of the world economy and is the second economic giant in the world. For this reason, countries preparing for FTA with China express concerns about the downfall of the domestic industry, in particular, the labor-intensive such as agriculture industry. As the major operating system, Chinese economy tends to become a more matured capitalism market. In spite of China still being a transitional country, the division of labor between Korea and China firmly settled after 20 years of establishing diplomatic ties with China. Moreover, Korean manufacturing firms' level of dependence on China is extremely high. The number of Korean firms is over 2 million and 70 percent of the top 300 firms have direct relations with China. Therefore, the China-Korea FTA, which has started to place negotiations on the table in 2012, may not only have a huge impact on the Asian economy, but on the world economy as well.

The importance of the Korea-China FTA cannot be overemphasized. In addition, the China-Korea FTA is expected to have great impact on the Korean labor market.
For Korea, the China-Korea FTA may cause massive unemployment in industries with weak competitiveness and moreover, labor-management conflicts may arise among workers impacted by the trade adjustment (Berzinskiene \& Juozaitiene, 2011).

Since the establishment of official diplomatic relations in 1992, China and Korea have been deepening their economic and non-economic relations and have been strengthening cooperation on both regional and multilateral forums, such as APEC, ASEM, ASEAN+3 $(10+3)$, and the WTO. After the Asian financial crisis, both countries have adopted FTAs as an important part of their strategic trade policy. In particular, on October 6, 2010, the 27-member European Union (EU), including Lithuania, signed a bilateral free trade agreement (FTA) with South Korea. The South Korea National Assembly and the EU Parliament have ratified the agreement. The agreement went into effect on July 1, 2011. The South Korea-EU FTA is the largest FTA in terms of market size into which South Korea has entered. The KOR-EU FTA reflects the EU and South Korean trade strategies in order to use FTAs to strengthen their economic ties outside their home regions. As relevant information for the readers, Lithuania in the EU 
has the high weight on electronics and machinery in terms of its volume of exports $(12.4 \%)$ and imports $(17.9 \%)$. Textiles occupy a high weight in terms of export volume $(11.7 \%)$, whereas vehicle and transportation equipment occupy a high weight in terms of import volume (17.9\%) (The Korea International Trade Association, 2012). As the aforementioned industries also occupy a high weight in the trade volume between China and Korea, there is no doubt that the China-Korea FTA, linked with the KOR-EU FTA, will definitely affect the Lithuanian economy

Additionally, since the signing of the Korea-U.S. FTA, China has been actively expressing its intention for the China-Korea FTA to secure a political and economic leadership in Asia. Meanwhile, the Korean government is cautious of pursuing the China-Korea FTA due to its experience of social tension after the closing of negotiations in the Korea-U.S. FTA.

The goal of this study is to assess empirically the impact of the China-Korea FTA on the industrial competitiveness and labor market of both countries. In order to achieve this goal, this study involved the following specific tasks:

- Building up the GTAP-CGE model on the impact of the China-Korea FTA on employment.

- Conducting the Fuzzy-Delphi survey of a panel of experts for the qualitative assessment on the ChinaKorea FTA.

- Suggesting negotiation strategy and institutional preparation for countries seeking for FTA with China.

\section{Method}

Over the years, there have been many studies regarding the economic effects and impact of the ChinaKorea FTA. For example, (Cheong, 2006) identified the effect of the China-Korea FTA by industry using a CGE model. Lee and Park (2005), according to their results, suggested the establishment of East Asian Free Trade Zone because the trade creation from free trade would be greater than the adverse effects of the trade diversion in the scenario of China-Japan-Korea FTA or ASEAN. Other major studies include (Sally, 2006; Lee \& Park, 2007; Low, 2003; Baldwin, 2006; Tongzon, 2005; Soesastro, 2006). These studies used a quantitative analysis to discuss the positive effects of the regional integration or FTAs in East Asia, including China, on the economy of the participating countries. The studies above focus on the quantization of the macroeconomic effect or the industrial effect of FTA on the Korean economy.

The FTA not only affects quantitative changes of macroeconomic variables, but causes qualitative changes in the economic structure, such as industrial competitiveness, or in the labor system. For this type of qualitative analysis, the Delphi survey, which analyzes the opinions of experts, is quite effective. In this survey of experts, although the panel of experts may have professional knowledge in the trends of the industry or the labor market, judging and predicting the consequences of the signing of FTA pertains many uncertainties. At times, it is difficult for experts to be certain about their predictions of the economic and qualitative effects of FTA based on their prior knowledge or literature research. In this case, the
Fuzzy Set Theory is used to reflect the ambiguity of the qualitative analysis in the evaluation process. More specifically, the Fuzzy Set Theory is used to reflect systematically the uncertainties and inaccuracies in the judgment process. Cases using the Fuzzy Theory in identifying the effect of policy change include (Kooten et at., 2001), who identified the effect of forest preservation policy amidst the uncertainties, and Moon and Lee (2005), who assessed expert opinions on the changes of science and technology policies of major countries around the world. Rhee et al., (2007) used the Fuzzy Set Theory to estimate the qualitative effect of the job creation policy in Korea; Rhee, (2007) discussed the possibility of applying the Fuzzy Theory in the judgment of experts on a policy effect. This study empirically assesses the impact of the China-Korea FTA on the industrial competitiveness and labor market of both countries. Before carrying out a survey targeting industry and labor experts, we simulate the GTAP (Global Trade Analysis Project)-CGE model. The simulation results have been provided to both committee members as basic information on the survey; then, the members answered the question about the impact on both countries' reference based on the simulation results. The Fuzzy method was used to deduct an ideal negotiation strategy and policy implications after observing the results of the GTAP-CGE simulation model. In other words, the quantitative effect of the China-Korea FTA was derived using the GTAP-CGE model while the qualitative effect and negotiation strategy was identified using the Fuzzy method, which takes into consideration the uncertainties that experts may have in judging the policy effect into a traditional Delphi survey (Lashgari et al., 2012). This study is the first to attempt this methodology.

The analysis procedure first begins with the organization of an Advisory Committee on the effects of the China-Korea FTA, an Industry Committee, and a Labor Committee. The Industry Committee predicts the macroeconomic effects and the employment effect of the China-Korea FTA using the GTAP-CGE model, and further prepares a report on the problems and unrealities of the prediction model (Hertel, 1997).

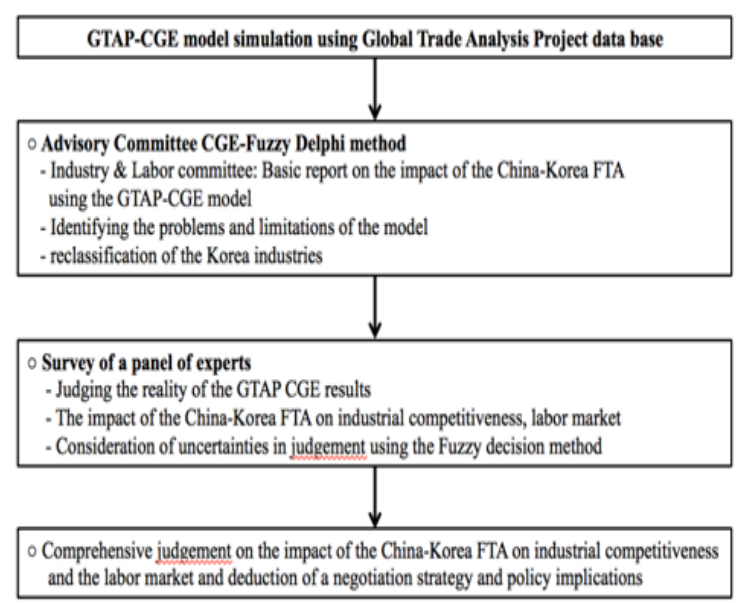

Figure 1. CGE-Fuzzy Delphi Process

The Labor Committee analyzes and discusses the qualitative effect of changes in the labor system and labor- 
management disputes due to the signing of the ChinaKorea FTA and prepares a report. Based on the discussions of the two committees, a Fuzzy-Delphi survey for a panel of experts is developed. Then, the survey of the panel of experts is conducted with the prepared reports and the developed questionnaire. In predicting the impact of the China-Korea FTA on the Korean economy, experts may have uncertainties in their judgment. In order to consider this uncertainty of judgment in the decision making, the Fuzzy method is used.

\section{Model for the Fuzzy Decision}

The introduction to this methodology is as follows. The Fuzzy Set Theory (Zadeh, 1965) systematically addresses the uncertainties or inaccuracies stemming from the vagueness of language. The Fuzzy Set Theory is applied to AHP (Analytic Hierarchy Process) (Saaty, 1994, 1996) or MAUT (Multi-Attribute Utility Theory) (Keeney, 1992), which uses the Likert scale to induce the accuracy of judgment (Tsaur et al., 2002) In this study, to evaluate the policy effect of the China-Korea FTA by industry, the Fuzzy Set Theory was designed to measure the impact by industry through Likert Scale questions and an evaluation of confidence judgment. The calculation of the Fuzzy decision methodology is as follows. First, the number (N) of evaluators and questions (R) is established to evaluate the effect of the China-Korea FTA. For instance,

$$
\begin{aligned}
& E=\left\{E_{i} \mid i=1,2, \ldots . ., N\right\} \\
& C=\left\{E_{t} \mid i=1,2, \ldots . ., R\right\}
\end{aligned}
$$

Here, $i$ is the evaluator, $E$ is the aggregate of the evaluators, $t$ is the judgment making questions, and $C$ is the aggregate of all questions. Next, the linguistic value $x$, which refers to the linguistic scale, and the level of confidence for each question as well as the collective linguistic valued, $P(x)$ and $S(y)$, are defined. For instance, interviewees are asked to make a decision on the question, "Based on your evaluation and criticism of the attached 'China-Korea FTA impact report' and your professional knowledge, what impact will the China-Korea FTA have on the Korean labor market?" The options are, Linguistic scale, $P=\{$ Very Unfavorable, Unfavorable, Average, Favorable, Very Favorable $\}$ and the Level of confidence of judgment, $S=\{$ Very Uncertain, Uncertain, Average, Certain, Very Certain S Second, the Fuzzy number is established. Dubois and Prade (1978) defined the Fuzzy number and explained the meaning and characteristics of this number. For instance, if the Fuzzy number, which is made up of three elements, is given as $M=(a, b, c)$, the membership function $f_{M}(x)$ can be expressed as follows.

$$
f_{M}(x)=\left\{\begin{array}{l}
\frac{x-a}{b-a}, \text { for } a \leq x \leq b \\
\frac{x-c}{b-c}, \text { for } b \leq x \leq c \\
o, \text { otherwise }
\end{array}\right.
$$

Here, $a, c$ and, $x$ each represent the maximum, minimum and mean value of the Fuzzy number $M$

Third, the linguistic scale and the level of confidence of the decision are defined. For instance, the Fuzzy number, which corresponds with the linguistic scale $(P)$ and the level of confidence $(S)$, is corresponded as follows.

$$
P_{t i}=\left(a_{t i}, b_{t i}, c_{t i}\right), S_{t i}=\left(o_{t i}, p_{t i}, q_{t i}\right)
$$

If the evaluator is presented with five selectable linguistic values, the Fuzzy number, which consists of three elements, can be sequentially corresponded, as in

\begin{tabular}{|c|c|c|}
\hline \multicolumn{2}{|c|}{ Linguistic scale } & \multirow{2}{*}{$\begin{array}{c}\text { Level of confidence } \\
\text { of judgment } \\
\text { Fuzzy Number }= \\
\left(\mathbf{o}_{\mathrm{t}}, \mathbf{p}_{\mathrm{t}}, \mathbf{q}_{\mathrm{t}}\right)\end{array}$} \\
\hline Linguistic value & $\begin{array}{c}\text { Fuzzy Number = } \\
\left(\mathbf{a}_{\mathbf{t}}, \mathbf{b}_{\mathbf{t i}}, \mathbf{c}_{\mathbf{t}}\right)\end{array}$ & \\
\hline 1) Very Unfavorable & $(0.00,0.00,0.25)$ & $(0.00,0.00,0.25)$ \\
\hline 2) Unfavorable & $(0.00,0.25,0.50)$ & $(0.00,0.25,0.50)$ \\
\hline 3) Fair & $(0.25,0.50,0.75)$ & $(0.25,0.50,0.75)$ \\
\hline 4) Favorable & $(0.50,0.75,1.00)$ & $(0.50,0.75,1.00)$ \\
\hline 5) Very Favorable & $(0.75,1.00,1.00)$ & $(0.75,1.00,1.00)$ \\
\hline
\end{tabular}
$<$ Table $1>$, for the values expressed in $1 / 4$ intervals.

Table 1

Fuzzy number and linguistic value

Fourth, the fuzzy confidence index of each individual evaluator is calculated. The average method is used to calculate the fuzzy confidence index (Buckley, 1985).

$$
\begin{aligned}
& F_{i} \cong\left(Y_{i}, Q_{i}, Z_{i}\right), \\
& \text { where } \quad Y_{i}=\left(a_{i t} \times o_{i t}\right) / R, \quad Q_{i}=\left(b_{i t} \times p_{i t}\right) / R, \\
& Z_{i}=\left(c_{i t} \times q o_{i t}\right) / R
\end{aligned}
$$

Here, $R$ is the number of questions; the elements of the fuzzy confidence index are $Y_{i}, Q_{i}$, and $Z_{i}$. Fifth, the total integral values of the fuzzy confidence index of each individual question are calculated. The total integral values, $I\left(F_{i}\right)$ of the fuzzy confidence index $\left(F_{i}\right)$, of evaluator $i$ is as follows.

$$
I\left(F_{i}\right)=\frac{1}{2}\left[\alpha Z_{i}+Q_{i}+(1-\alpha) Y_{i}\right]
$$

Here, $\alpha$ is the optimum index. Specifically, the level of optimism of the evaluator on the impact of the FTA is commonly assumed to be $\alpha=0.5$. This implies that the decision maker is neutral when making a decision. To calculate the evaluation scores of each subject, the total integral value is normalized, as in formula (7); this is known as the fuzzy evaluation score for the China-Korea FTA effect by evaluator $i$.

$$
G_{i}^{F}=\operatorname{norm}\left(I\left(F_{i}\right)\right)
$$

Through this process, the average fuzzy evaluation score of the evaluators can be calculated as follows.

$$
G^{F}=\frac{1}{N} \sum_{i} G_{i}^{F}
$$


Joonmo Cho, Kwangho Woo, Hae-Chun Rhee. Industrial and Employment Effect of China-Korea FTA: Negotiation...

\section{Analysis}

\section{Prediction results of the GTAP CGE model}

The prediction results of the GTAP-CGE model are as follows (see <Table 2>). First, the Korea and China tariffs reduction scenario for China-Korea FTA negotiations was established as follows. The scenarios were divided into high level FTA (scenario 1), mid-level FTA (scenario 2), and low level FTA (scenario 3).

Scenario of the China-Korea FTA

\begin{tabular}{|c|c|c|c|c|c|c|}
\hline \multirow[b]{2}{*}{ Scenario } & & \multirow{2}{*}{$\begin{array}{c}\text { Korea } \\
\text { Primary } \\
\text { Industry }\end{array}$} & \multicolumn{3}{|c|}{ China (Manufacture Sector) } & \multirow{2}{*}{$\begin{array}{c}\text { Korea \& China } \\
\text { Other } \\
\text { Manufactured } \\
\text { Goods }\end{array}$} \\
\hline & & & $\begin{array}{c}\text { Transportation } \\
\text { Equipment }\end{array}$ & $\begin{array}{l}\text { Electric \& Electronic } \\
\text { Manufacturing }\end{array}$ & $\begin{array}{c}\text { General } \\
\text { Machinery }\end{array}$ & \\
\hline Scenario 1 & $\begin{array}{l}\text { High level } \\
\text { FTA }\end{array}$ & Complete removal & Complete removal & Complete removal & Complete removal & $\begin{array}{l}\text { Complete } \\
\text { removal }\end{array}$ \\
\hline Scenario 2 & $\begin{array}{l}\text { Mid-level } \\
\text { FTA }\end{array}$ & $75 \%$ Reduction & $90 \%$ Reduction & $80 \%$ Reduction & $80 \%$ Reduction & $\begin{array}{l}\text { Complete } \\
\text { removal }\end{array}$ \\
\hline
\end{tabular}

First, it is predicted that the GDP of both countries will improve with the conclusion of the FTA (see <Table $3>$ ). According to the scenario, Korea's GDP will increase by $3.1 \sim 5.0 \%$. It is expected that the GDP will increase more with a greater scope of a market opening. If the current tariffs are completely removed for all industries, Korea's GDP will increase by $5 \%$. In the mid-level FTA (scenario 2), Korea's GDP will increase by $3.9 \%$ and that of China by $0.4 \%$, and at the low level (scenario 3), Korea will increase by $3.12 \%$ while China will see an increase of $0.34 \%$. China's national income will increase with the China-Korea FTA; yet, the margin of increase is expected to be lower than that of Korea. The GDP increase of China being lower than Korea is explained by the difference in the industry and trade structures. For instance, China's foreign dependency is high, similar to Korea; however, Korea's relative importance in the Chinese economy is lower than China's relative importance in the Korean economy. In the overall foreign dependency as well, Korea is higher than China, which explains as to why the economic effect of the FTA is greater for Korea than for China.

Table 3

GDP Increase Effect of the China-Korea FTA

\begin{tabular}{cccc}
\hline & Scenario 1 & Scenario 2 & Scenario 3 \\
GDP of Korea & $5.02 \%$ increase & $3.86 \%$ increase & $3.12 \%$ increase \\
GDP of China & $0.43 \%$ increase & $0.39 \%$ increase & $0.34 \%$ increase \\
\hline
\end{tabular}

In signing the China-Korea FTA, the industrial production of Korea will increase more with a higher level of trade liberalization, such as the removal of tariffs (see $<$ Table 4>).

Table 4

Production and employment in Korea on the China-Korea FTA

\begin{tabular}{|c|c|c|c|c|c|c|}
\hline \multirow{2}{*}{ Sector } & \multicolumn{3}{|c|}{ Production growth rate $(\%)$} & \multicolumn{3}{|c|}{ Number of employment (person) } \\
\hline & Scenario 1 & Scenario 2 & Scenario 3 & Scenario 1 & Scenario 2 & Scenario 3 \\
\hline Primary industry & $-19.20 \%$ & $-10.5 \%$ & $-4.50 \%$ & NA & NA & NA \\
\hline Mining & $-3.00 \%$ & $-2.1 \%$ & $-1.60 \%$ & NA & NA & NA \\
\hline Food products \& beverages & $0.90 \%$ & $0.7 \%$ & $0.60 \%$ & 32,449 & 19,271 & 11,402 \\
\hline Textiles \& clothing & $12.30 \%$ & $9.70 \%$ & $7.60 \%$ & 62,437 & 47,819 & 36,740 \\
\hline Chemicals & $7.20 \%$ & $6.90 \%$ & $6.60 \%$ & 36,777 & 32,499 & 29,813 \\
\hline Transportation equipment & $-1.30 \%$ & $-1.00 \%$ & $-1.10 \%$ & 902 & 483 & -193 \\
\hline Electric \& electronic products & $1.00 \%$ & $0.50 \%$ & $-0.50 \%$ & 22,065 & 15,966 & 8,876 \\
\hline General machinery & $1.80 \%$ & $1.00 \%$ & $2.70 \%$ & 15,418 & 10,750 & 15,454 \\
\hline Other manufacturing & $8.20 \%$ & $7.20 \%$ & $6.50 \%$ & 31,162 & 26,038 & 22,557 \\
\hline Service & $7.30 \%$ & $5.60 \%$ & $4.60 \%$ & NA & NA & NA \\
\hline Mean of All Sectors & $4.30 \%$ & $3.70 \%$ & $3.40 \%$ & 218,973 & 169,170 & 141,113 \\
\hline
\end{tabular}

If both countries remove tariffs (scenario 1), the textiles \& clothing sector will increase the most, whereas the chemicals and general machinery will increase as well. This is because there is a comparative advantage within the industries that can see an increase in exports to China. In fact, there are many industries in Korea with export specialization within the China-Korea trade. However, on the other hand, production in the primary industry will contract. In the manufacturing sector, it is predicted that the production of transportation equipment (mostly automobiles) will decline. Meanwhile, employment will increase overall. In the case of the total removal of tariffs, 220,000 new jobs will be created. Job creation in the textiles \& clothing industry will be the highest with 62,000 jobs, followed by chemicals and electric \& electronic products. 
If we observe the impact of the China-Korea FTA on the industrial production of China, it is predicted that the increase in total production will be higher with a greater level of opening (see <Table 5>).

Table 5

Production in China on the China-Korea FTA

\begin{tabular}{llll}
\hline \multirow{2}{*}{ Sector } & \multicolumn{3}{c}{ Production growth rate (\%) } \\
& Scenario 1 & Scenario 2 & Scenario 3 \\
\hline Primary industry & $2.71 \%$ & $1.81 \%$ & $1.15 \%$ \\
Mining & $0.26 \%$ & $0.26 \%$ & $0.26 \%$ \\
Food products \& & $1.04 \%$ & $1.02 \%$ & $0.99 \%$ \\
beverages & & & \\
Textiles \& clothing & $-0.46 \%$ & $-0.15 \%$ & $0.12 \%$ \\
Chemicals & $-0.47 \%$ & $-0.50 \%$ & $-0.53 \%$ \\
Iron \& steel & $0.20 \%$ & $0.20 \%$ & $0.17 \%$ \\
Transportation equipment & $0.24 \%$ & $0.29 \%$ & $0.36 \%$ \\
Electric \& electronic & $1.76 \%$ & $1.50 \%$ & $1.35 \%$ \\
products & & & \\
General machinery & $0.20 \%$ & $0.31 \%$ & $0.15 \%$ \\
Other manufacturing & $-0.28 \%$ & $-0.18 \%$ & $-0.10 \%$ \\
Service & $0.37 \%$ & $0.38 \%$ & $0.36 \%$ \\
Mean of All Sectors & $0.51 \%$ & $0.43 \%$ & $0.35 \%$ \\
\hline
\end{tabular}

If the tariffs of both countries are completely removed, the production increase of the primary industry in China will be the highest, followed by food products \& beverages, electric \& electronic products, and general machinery. In the GTAP CGE model, the impact of FTA on employment in China cannot be identified due to the limitations of the data.

The simulation results of the CGE model have several limitations, such as the problem of simulation data and the point of time of prediction, immobility of serious parameters, limitations in reflecting the effects of restructuring, and distortion of the measurement of the employment effect. This study conducts the Delphi survey of the panel of experts to complement the results of the GTAP CGE model.

2. Results of the Delphi survey

(1) Evaluation of impact on industrial competitiveness and employment in Korea

The Delphi survey took into consideration the uncertainties of the judgment in the panel of experts by using the Fuzzy decision methodology. The industrial competitiveness in Korea, in the case of the China-Korea FTA, has been evaluated as follows (see <Table 6>).

Table 6

Ranking of Korea's industrial competitiveness from the China-Korea FTA

\begin{tabular}{|c|c|c|c|c|}
\hline \multirow{2}{*}{ Competitiveness } & \multirow{2}{*}{ Sector } & \multicolumn{3}{|c|}{ Evaluation score of industrial competitiveness } \\
\hline & & Simple score & Fuzzy score & Mean \\
\hline \multirow[t]{3}{*}{ Very favorable } & 12. Machinery & 3.91 & 3.91 & 3.91 \\
\hline & 13. Electric \& electronic products & 3.83 & 3.69 & 3.76 \\
\hline & 6. Chemicals \& plastic products & 3.69 & 3.76 & 3.73 \\
\hline \multirow[t]{3}{*}{ Favorable } & 4. Textiles \& clothing & 3.09 & 3.37 & 3.23 \\
\hline & 14. Automobiles \& parts & 3.27 & 3.19 & 3.23 \\
\hline & 7. Petroleum \& coal products & 3.36 & 3.08 & 3.22 \\
\hline \multirow[t]{3}{*}{ Average } & 9. Steel & 3.18 & 3.1 & 3.14 \\
\hline & 15. Other transportation equipment & 3.18 & 2.89 & 3.04 \\
\hline & 8. Non-metal mineral products & 3.09 & 2.89 & 2.99 \\
\hline \multirow[t]{6}{*}{ Unfavorable } & 11. Metal products & 3 & 2.63 & 2.82 \\
\hline & 10. Non-ferrous metals & 2.91 & 2.66 & 2.79 \\
\hline & 16. Other manufacturing & 2.83 & 2.51 & 2.67 \\
\hline & 3. Food products and beverages & 2.55 & 2.29 & 2.42 \\
\hline & 5. Wood \& furniture & 2.45 & 2.05 & 2.25 \\
\hline & 2. Mining & 2.09 & 1.93 & 2.01 \\
\hline \multirow[t]{2}{*}{ Very unfavorable } & 1. Agriculture \& Fishery & 1.18 & 1.17 & 1.18 \\
\hline & ean of All Sectors & 3.36 & 3.12 & 3.24 \\
\hline
\end{tabular}

The simple evaluation score of the overall industry is 3.36 and the fuzzy evaluation score is 3.12. This implies that the China-Korea FTA will be favorable above the average level for Korea's industrial competitiveness.

In order to decide the priority of industrial production in Korea, the industries were divided into five groups. According to these criteria, the industries that would gain a significant advantage in industrial production due to the China-Korea FTA are machinery, electrical \& electronic goods, and chemicals \& plastics, followed by textiles \& clothing, automobiles \& parts, petroleum \& coal products, and steel. Industries that would not be affected much are other transportation equipment and non-metal mineral products. Industries that would be disadvantaged are metal products, nonferrous metals, other manufacturing, processed foods, and wood furniture. Finally, the industries that would be placed at a significant disadvantage are mining, and agriculture, forestry, and fisheries.

In the perspective of employment in Korea, the simple evaluation score of the overall industry is 3.18 and the fuzzy evaluation score is 3.01. In the overall industry, employment in Korea due to the China-Korea FTA scored above average (3); yet, it will not be greatly affected or will only be slightly favorable.

Experts assessed that in terms of employment, the China-Korea FTA will not be greatly favorable compared to their industrial competitiveness (see $\langle$ Table 7$\rangle$ ). For instance, the average of the two scores in industrial competitiveness is 3.24 and the average score of the confidence of the assessment is 3.36. Meanwhile, regarding the impact on employment, the average of the two scores is 3.10 while the average of confidence is 3.27 . 
This means that the China-Korea FTA is favorable to the industrial production in Korea, but relatively not that favorable in employment. The lower score for the confidence of the impact on employment (3.27) compared to the confidence of the industrial production (3.36) shows that experts are not confident about the positive effects that the China-Korea FTA will have on employment as it will have on industrial competitiveness. This hints that there is no mechanism to ensure that the increase in industrial production due to the China-Korea FTA will lead to an increase in employment.

In deciding the level of advantage and disadvantage to employment in Korea, a score of above 3.5 is very favorable, 3.1 to 3.5 is favorable, 2.9 to 3.1 is average, 2.1 to 2.9 is unfavorable, and below 2.1 is very unfavorable. Based on this criteria, the very favorable industry in terms of employment in Korea due to the China-Korea FTA is machinery; the favorable industries are chemicals \& plastic products, electric \& electronic goods, and automobiles \& parts. The average industries are petroleum \& coal products, steel, other transportation equipment, textiles \& clothing, and other manufacturing. The industries that are unfavorable are non-metal mineral products, nonferrous metals, metal products, processed foods, and mining, and the very unfavorable industries are wood furniture, and agriculture, forestry, and fisheries.

Table 7

Ranking of Korea's impact on employment from the ChinaKorea FTA

\begin{tabular}{|c|c|c|c|c|}
\hline \multirow{2}{*}{$\begin{array}{l}\text { Advantage } \\
\text { of } \\
\text { employment } \\
\text { impact }\end{array}$} & \multirow[t]{2}{*}{ Sector } & \multicolumn{3}{|c|}{$\begin{array}{c}\text { Evaluation score of } \\
\text { employment impact (Korea) }\end{array}$} \\
\hline & & $\begin{array}{l}\text { Simple } \\
\text { score }\end{array}$ & $\begin{array}{l}\text { Fuzzy } \\
\text { score }\end{array}$ & Mean \\
\hline \multirow{3}{*}{$\begin{array}{l}\text { Very } \\
\text { favorable }\end{array}$} & 12. Machinery & 3.55 & 3.58 & 3.57 \\
\hline & $\begin{array}{l}\text { 6. Chemicals \& } \\
\text { plastic products }\end{array}$ & 3.46 & 3.46 & 3.46 \\
\hline & $\begin{array}{l}\text { 13. Electric \& } \\
\text { electronic products }\end{array}$ & 3.33 & 3.32 & 3.33 \\
\hline \multirow[t]{3}{*}{ Favorable } & $\begin{array}{l}\text { 14. Automobiles \& } \\
\text { parts }\end{array}$ & 3.18 & 3.05 & 3.12 \\
\hline & $\begin{array}{l}\text { 7. Petroleum \& coal } \\
\text { products }\end{array}$ & 3.27 & 2.86 & 3.07 \\
\hline & 9. Iron \& steel & 3.09 & 2.88 & 2.99 \\
\hline \multirow[t]{3}{*}{ Average } & $\begin{array}{l}\text { 15. Other } \\
\text { transportation } \\
\text { equipment }\end{array}$ & 3.09 & 2.82 & 2.96 \\
\hline & $\begin{array}{l}\text { 4. Textiles \& } \\
\text { clothing }\end{array}$ & 2.91 & 2.94 & 2.93 \\
\hline & $\begin{array}{l}\text { 16. Other } \\
\text { manufacturing }\end{array}$ & 3 & 2.82 & 2.91 \\
\hline \multirow[t]{6}{*}{ Unfavorable } & $\begin{array}{l}\text { 8. Non-metal mineral } \\
\text { products }\end{array}$ & 3 & 2.71 & 2.86 \\
\hline & $\begin{array}{l}\text { 10. Non-ferrous } \\
\text { metals }\end{array}$ & 3 & 2.63 & 2.82 \\
\hline & 11. Metal products & 3 & 2.52 & 2.76 \\
\hline & $\begin{array}{l}\text { 3. Food and } \\
\text { beverages }\end{array}$ & 2.64 & 2.41 & 2.53 \\
\hline & 2. Mining & 2.18 & 2.03 & 2.11 \\
\hline & 5. Wood \& furniture & 2.27 & 1.91 & 2.09 \\
\hline $\begin{array}{l}\text { Very } \\
\text { unfavorable }\end{array}$ & $\begin{array}{l}\text { 1. Agriculture \& } \\
\text { Fishery }\end{array}$ & 1.45 & 1.69 & 1.57 \\
\hline \multicolumn{2}{|c|}{ Mean of All Sectors } & 3.18 & 3.01 & 3.1 \\
\hline
\end{tabular}

(2) Evaluation of impact on industrial competitiveness and employment in China. The opinions of the panel of experts on the impact of industrial production in China due to the China-Korea FTA are as follows (see <Table $8>$ ). For the overall industry of China, the simple evaluation score is 3.73 and the fuzzy evaluation score is 2.43. The average of these two scores is 3.08 and the confidence of the judgment of evaluation for the overall industry is 3.27. This means that in terms of industrial production, the China-Korea FTA will be favorable to China, as its scores are above average (3). The big difference between the simple evaluation score and the fuzzy evaluation score shows that evaluators were largely divided in their confidence for the evaluation of industrial competitiveness. More specifically, compared to the data available for the evaluation of industrial production in Korea, the evaluators lacked data for the evaluation of industrial production in China.

Table 8

Ranking of China's industrial competitiveness from the China-Korea FTA

\begin{tabular}{|c|c|c|c|c|}
\hline \multirow{2}{*}{$\begin{array}{l}\text { Competiti- } \\
\text { veness }\end{array}$} & \multirow{2}{*}{$\begin{array}{l}\text { China industry } \\
\text { sector }\end{array}$} & \multicolumn{3}{|c|}{$\begin{array}{c}\text { Evaluation score of industrial } \\
\text { competitiveness }\end{array}$} \\
\hline & & $\begin{array}{l}\text { Simple } \\
\text { score }\end{array}$ & $\begin{array}{l}\text { Fuzzy } \\
\text { score }\end{array}$ & Mean \\
\hline \multirow[t]{3}{*}{$\begin{array}{l}\text { Very } \\
\text { favorable }\end{array}$} & $\begin{array}{l}\text { 1. Agriculture \& } \\
\text { Fishery }\end{array}$ & 4.82 & 4.82 & 4.82 \\
\hline & $\begin{array}{l}\text { 4. Textiles \& } \\
\text { clothing }\end{array}$ & 4.09 & 3.26 & 3.67 \\
\hline & 5. Wood \& furniture & 4.09 & 3.12 & 3.61 \\
\hline \multirow{2}{*}{$\begin{array}{l}\text { Favorable } \\
\text { General }\end{array}$} & 2. Mining & 3.91 & 2.98 & 3.45 \\
\hline & $\begin{array}{l}\text { 3. Food products } \\
\text { and beverages }\end{array}$ & 3.55 & 2.54 & 3.04 \\
\hline \multirow[t]{11}{*}{ Unfavorable } & $\begin{array}{l}\text { 15. Other } \\
\text { transportation } \\
\text { equipment }\end{array}$ & 3.18 & 2.08 & 2.63 \\
\hline & $\begin{array}{l}\text { 16. Other } \\
\text { manufacturing }\end{array}$ & 3.33 & 1.9 & 2.62 \\
\hline & $\begin{array}{l}\text { 14. Automobiles \& } \\
\text { parts }\end{array}$ & 3 & 2.01 & 2.5 \\
\hline & 9. Steel & 2.91 & 2.08 & 2.5 \\
\hline & $\begin{array}{l}\text { 7. Petroleum \& coal } \\
\text { products }\end{array}$ & 3.09 & 1.78 & 2.44 \\
\hline & $\begin{array}{l}\text { 10. Non-ferrous } \\
\text { metals }\end{array}$ & 2.91 & 1.89 & 2.4 \\
\hline & 11. Metal products & 2.91 & 1.74 & 2.33 \\
\hline & $\begin{array}{l}\text { 13. Electric \& } \\
\text { electronic products }\end{array}$ & 2.92 & 1.73 & 2.32 \\
\hline & $\begin{array}{l}\text { 8. Non-metal } \\
\text { mineral products }\end{array}$ & 3 & 1.63 & 2.31 \\
\hline & $\begin{array}{l}\text { 6. Chemicals \& } \\
\text { plastic products }\end{array}$ & 2.69 & 1.6 & 2.15 \\
\hline & 12. Machinery & 2.73 & 1.44 & 2.08 \\
\hline \multicolumn{2}{|c|}{ Mean of All Sectors } & 3.73 & 2.43 & 3.08 \\
\hline
\end{tabular}

The impact of the China-Korea FTA on employment in China is as follows (see <Table 9>).

In the perspective of the overall industry, the simple evaluation score is 3.64 , the fuzzy evaluation score is 2.15 , and the average of the two is 2.9. This means that the China-Korea FTA will not greatly affect the employment in China for the industry as a whole. 
Table 9

Ranking of China's impact on employment from the China-Korea FTA

\begin{tabular}{|c|c|c|c|c|}
\hline \multirow{2}{*}{$\begin{array}{c}\text { Advantage } \\
\text { of } \\
\text { employment } \\
\text { impact }\end{array}$} & \multirow[t]{2}{*}{ Sector } & \multicolumn{3}{|c|}{$\begin{array}{c}\text { Evaluation score of } \\
\text { employment } \\
\text { impact(China) }\end{array}$} \\
\hline & & $\begin{array}{l}\text { Simple } \\
\text { score }\end{array}$ & $\begin{array}{l}\text { Fuzzy } \\
\text { score }\end{array}$ & Mean \\
\hline \multirow{4}{*}{$\begin{array}{l}\text { Very } \\
\text { favorable }\end{array}$} & 1.Agriculture \& Fishery & 4.64 & 4.64 & 4.64 \\
\hline & 4. Textiles \& clothing & 4.09 & 3.22 & 3.65 \\
\hline & 2. Mining & 4 & 3.27 & 3.64 \\
\hline & 5. Wood \& furniture & 4.18 & 3.03 & 3.6 \\
\hline General & $\begin{array}{l}\text { 3. Food products and } \\
\text { beverages }\end{array}$ & 3.73 & 2.57 & 3.15 \\
\hline \multirow[t]{11}{*}{ Unfavorable } & $\begin{array}{l}\text { 15. Other transportation } \\
\text { equipment }\end{array}$ & 3.27 & 2.12 & 2.69 \\
\hline & 14. Automobiles \& parts & 3.18 & 2.12 & 2.65 \\
\hline & 9. Iron \& steel & 3 & 2.15 & 2.58 \\
\hline & $\begin{array}{l}\text { 7. Petroleum \& coal } \\
\text { products }\end{array}$ & 3.27 & 1.85 & 2.56 \\
\hline & $\begin{array}{l}\text { 8. Non-metal mineral } \\
\text { products }\end{array}$ & 3.27 & 1.85 & 2.56 \\
\hline & 16. Other manufacturing & 3.25 & 1.8 & 2.52 \\
\hline & 10. Non-ferrous metals & 3 & 1.85 & 2.43 \\
\hline & $\begin{array}{l}\text { 13. Electric \& electronic } \\
\text { products }\end{array}$ & 3.08 & 1.66 & 2.37 \\
\hline & 11. Metal products & 3 & 1.7 & 2.35 \\
\hline & $\begin{array}{l}\text { 6. Chemicals \& plastic } \\
\text { products }\end{array}$ & 2.85 & 1.58 & 2.21 \\
\hline & 12. Machinery & 2.82 & 1.4 & 2.11 \\
\hline \multicolumn{2}{|c|}{ Mean of All Sectors } & 3.64 & 2.15 & 2.9 \\
\hline
\end{tabular}

The average confidence score for the evaluation of the impact on employment in China is 3 , which is lower than the average confidence score for Korea, 3.27. This implies that the optimistic view that employment will increase in China due to the China-Korea FTA is contradicting with the pessimistic view that employment will not increase, thus stating that the China-Korea FTA may not act positively on employment in China. As for the impact that the China-Korea FTA may have on employment in China by industry, four industries are expected to be very favorable in employment due to the China-Korea FTA; agriculture, forestry, and fisheries (1: 4.64), textiles \& clothing (4: 3.65), mining (2: 3.64), and wood furniture (5: 3.6). The favorable industry is processed foods (3: 3.15). All other industries, such as other transportation equipment (15: 2.69), automobile \& parts (14: 2.65), steel (9: 2.58), petroleum \& coal products (7: 2.56), non-metal mineral products $(8: 2.56)$, other manufacturing (16: 2.52$)$, nonferrous metals (10: 2.43), electrical \& electronic goods (13: 2.37), metal products (11: 2.35), chemicals \& plastics (6: 2.21), and machinery (12: 2.11$)$, are unfavorable.

(3) Industrial competitiveness and employment matrix of the China-Korea FTA

The industrial competitiveness matrix of the ChinaKorea FTA is as follows (see <Figure 2>).

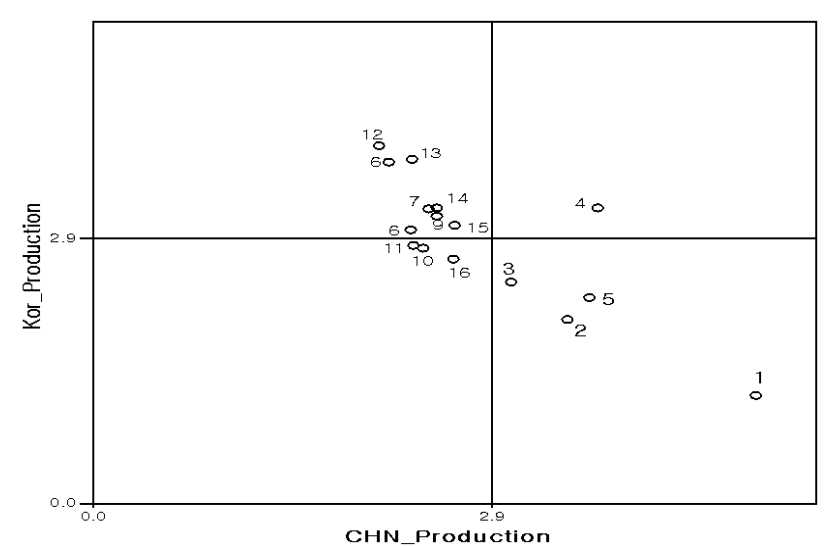

Figure 2. Industrial competitiveness matrix of the China-Korea FTA

The favorable industry for both Korea and China in the FTA is textiles \& clothing $(3.24,3.67)$. As for agriculture, forestry, and fisheries, Korea is at an absolute disadvantage, whereas China is very favorable. For mining and wood furniture, Korea is unfavorable and China is either favorable or very favorable. For processed foods $(2.42,3.04)$, Korea is unfavorable, whereas China is hardly affected. For machinery $(3.91,2.08)$, electrical \& electronic goods $(3.76,2.32)$, and chemicals \& plastics $(3.75,2.15)$, Korea is very favorable, whereas China is unfavorable, and for automobile \& parts $(3.23,2.5)$ and petroleum \& coal products $(3.22,2.44)$, Korea is favorable whereas China is unfavorable.

Therefore, in the case of the China-Korea FTA, processed foods, mining, wood furniture, and agriculture, forestry, and fisheries are industries where Korea is disadvantaged while China is fairly advantaged or much advantaged. However, in industries, such as machinery, electrical \& electronic goods, chemicals \& plastics, automobiles \& parts, and petroleum \& coal products, Korea has a relative advantage over China.

Next, the employment matrix of the China-Korea FTA is as follows (see <Figure $3>$ ). In terms of employment, agriculture, forestry, and fisheries $(1.57,4.64)$ are industries where Korea is at an absolute disadvantage, whereas China is very favorable. As for mining (2.11, $3.64)$ and wood furniture $(2.09,3.6)$, Korea is fairly unfavorable while China is very favorable. For processed foods $(2.53,3.15)$, Korea is unfavorable, whereas China is hardly affected. Textiles \& clothing $(2.93,3.65)$ is an industry where both Korea and China are either fairly favorable or non-affected. This industry is almost neutral in terms of employment. In machinery $(3.57,2.11)$, chemicals \& plastics $(3.46,2.21)$, and electrical \& electronic goods $(3.33,2.37)$, Korea is very favorable or favorable, whereas China is unfavorable. For automobiles $\&$ parts $(3.12,2.65)$, petroleum \& coal products $(3.07$, $2.56)$, other transportation equipment $(2.96,2.69)$, steel $(2.99,2.58)$, and other manufacturing $(2.91,2.52)$, Korea is hardly affected in terms of employment, whereas China is unfavorable. For non-metal mineral products (2.86, $2.56)$, nonferrous metals $(2.82,2.43)$, and metal products $(2.76,2.35)$, both countries are evaluated to be fairly unfavorable in terms of employment. 


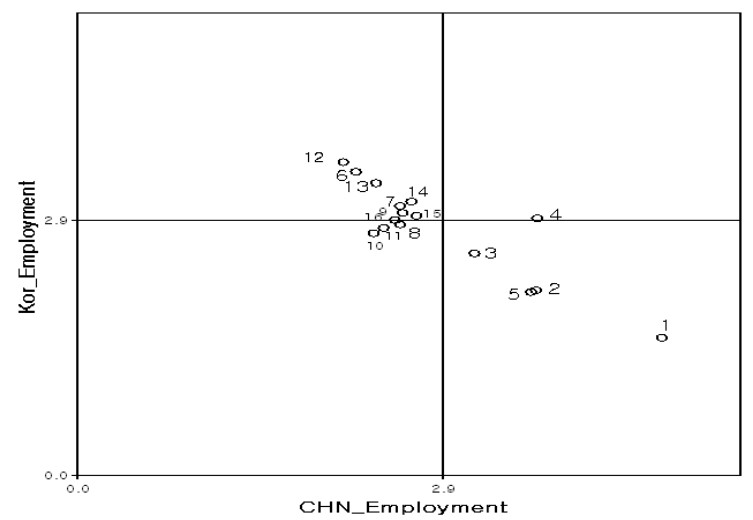

Figure 3. Employment matrix of the China-Korea FTA

Considering both industrial production and employment, the favorable industries for Korea in both categories are machinery, electrical \& electronic goods, and chemicals \& plastics. The industries that are clearly favorable for China in terms of both industrial production and employment are textiles \& clothing, mining, wood furniture, and agriculture, forestry, and fisheries. In the assessment of the industry overall, Korea has an advantage in industrial production and is hardly affected in employment, whereas China is both hardly affected in industrial production and employment. In other words, the China-Korea FTA is favorable to Korea in terms of industrial production; however, advantages in industrial production do not necessarily lead to employment. In comparison, China is neutral in both industrial production and employment (Cho et al., 1996, Cho \& Cho, 2011).

\section{Negotiation Strategy and Policy Implication}

\section{Negotiation strategy for the China-Korea FTA}

Based on the analysis results above, the impact of the China-Korea FTA on industrial competitiveness and employment can be classified as follows (see <Table 10>). First, the favorable sector (A) for both Korea and China is the textiles \& clothing industry. In this sector, the effects of the China-Korea FTA on industrial production and employment are positive. Specifically, Korea has an advantage in high value added products, such as synthetic regenerated fiber and synthetic fiber fabrics; yet, China is advantageous in labor intensive areas, such as leather and fur, leather clothing, fur clothing, and shoes. Second, the sectors where China is advantaged and Korea is disadvantaged (B) are processed foods, mining, wood furniture, and agriculture, forestry, and fisheries. Third, the sectors where Korea is advantaged and China is disadvantaged (C) are machinery, electrical \& electronic goods, chemicals \& plastics, automobiles \& parts, petroleum \& coal products, other transportation equipment, non-metal mineral products, and steel. The impact on employment is also similar to the impact on industrial production; however, other manufacturing is included, whereas non-metal mineral products is excluded (Cho, 2004). Fourth, the sector that should not be opened for Korea (D) in terms of both industrial production and employment is agriculture, forestry, and fisheries; there were no sectors that should not be opened for China (F).
The following negotiation strategy can be conceived. The first sector to reach an agreement is the textiles \& clothing industry, which is favorable to both Korea and China. For this sector, an agreement on joint opening can easily be reached. In terms of the impact on employment, workers who are impacted by a trade adjustment due to the China-Korea FTA will be less in this sector than for the overall industries (Cho \& Keum, 2004; Cho et al., 2010).

Next, the second agreement to be reached is a barter negotiation between the sectors that are favorable to China and unfavorable to Korea (B) with the sectors that are favorable to Korea and unfavorable to China (C). In the case of Korea, according to the negotiations, a negative impact could occur in the labor market for processed foods, furniture, and wood product, and the stability of labormanagement relations could be harmed. In particular, for processed foods, allowing partial safeguards, extension of the implementation period, and exclusion from the tariff removal list during the negotiations could alleviate domestic resistance. Finally, the third step is to negotiate the agriculture, forestry, and fisheries industries, which are classified as industries that should not be opened for Korea. For Korea, in return for excluding the agriculture, forestry, and fisheries industry from negotiations, it could accept China's demands in the second stage barter negotiations. Moreover, if the agriculture, forestry, and fisheries sector is included in the negotiations, a written provision of invoking safeguard measures and the extension of the implementation period should be sought. As a return service, the demands of China for machinery, electrical \& electronic goods, chemicals \& plastics, and automobiles \& parts could be met during negotiations, which would be a win-win strategy for both parties.

\section{Strategy for industrial readjustment and labor-} management conflict in Korea

According to the macro-model, the China-Korea FTA will have a positive effect on industry and employment. Furthermore, the results of the survey of experts demonstrate that the China-Korea FTA will have a positive effect on the Korean economy, excluding certain sectors, such as agriculture, forestry, and fisheries, and wood furniture. Although the China-Korea FTA would have positive effects for the industry overall, the industries that are weak in competitiveness will inevitably have to face restructuring. The readjustment strategy for workers subject to trade adjustment should be conducted in the perspective of labor-management relations than in the perspective of the industry.

The industries burdened by the China-Korea FTA are few, such as agriculture, forestry, and fisheries, mining, wood furniture, and processed foods, whereas the beneficiaries are many, such as machinery, chemicals \& plastics, electric \& electronic goods, automobiles, and petrochemicals. In this case, the class that suffers a loss is limited; however, the profits will go to the random majority. Because the beneficiaries are unclear, compensation is demanded to the government, which is the proxy of the random majority. The labor conflicts related to the ChinaKorea FTA should be prohibited from developing into a political issue and should be resolved as an economic problem. 
Classification of impact on industrial production and employment

\begin{tabular}{clll}
\hline Group & \multicolumn{1}{c}{ Competitiveness } & \multicolumn{1}{c}{ Industrial production } & \multicolumn{1}{c}{ Employment } \\
\hline A & Favorable for both Korea, China & 4. Textiles \& clothing, (All sectors) & 4. Textiles \& clothing, (All sectors) \\
B & Unfavorable for Korea, Favorable & 3. Food products and beverages, 2.Mining, 5. & 3. Food products and beverages, 2. Mining, 5. Wood \\
& for China & Wood \& furniture & \& furniture \\
C & Favorable for Korea, Unfavorable & 12. Machinery, 13. Electric \& electronic & 12. Machinery, 13. Electric \& electronic products, \\
& for China & products, 6. Chemicals \& plastic products, 14. & 6.Chemicals \& plastic products, 14. Automobiles \& \\
& & Automobiles \& parts, 7. Petroleum \& coal & parts, 7. Petroleum \& coal products, 15. Other \\
& & products, 15. Other transportation equipment, 8. & transportation equipment, 9. Iron \& steel, 16. Other \\
& & Non-metal mineral products, 9. Iron \& steel & manufacturing \\
D & Do not open for Korea & 1. Agriculture \& Fishery & 1. Agriculture \& Fishery \\
E & Do not open for China & None & None \\
\hline
\end{tabular}

For this, the Tripartite (Union-Employers-Government) Commission and other labor-management organizations by industry and business should attempt to draw a social consensus.

In the process of industrial restructuring, the Sector Council program for human resources development must be strengthened (Cho, 2005; Cho \& Kim, 2005; Cho \& Lee, 2007). For the industry as a whole, restructuring must be conducted smoothly through the Sector Council program. However, particularly for processed foods, mining, and wood furniture, which may be vulnerable in the restructuring process or machinery, electrical \& electronic goods, chemicals, and automobiles, which inevitably will be subject to some extent of restructuring during negotiations, the Sector Council must be strengthened.

Further, government support systems must be diversified for displaced workers and companies from trade adjustment due to the FTA. In particular, in labor systems, vocational training must not be limited to workers impacted by the trade adjustment due to the China-Korea FTA, but must be reorganized to meet the needs of the supply and demand of labor from industrial restructuring. Training programs must be focused to meet the demands of labor increase in industries where competitiveness will be strengthened and production will be increased in the longterm, such as machinery, electrical \& electronic goods, automobiles \& parts, and petrochemicals while at the same time, assist the reemployment of workers impacted by trade adjustment into these industries (Cho \& Kim, 2001).

It is also desirable to establish a contribution system for trade liberalization profits to be used as a source of funding for the compensation of damages engendered by the China-Korea FTA. More specifically, a percentage of the trade profits of exporters, importers, and producers who will gain additional profit from the FTA should be collected as a contribution to be used for the compensation fund for parties that will suffer a loss.

\section{Conclusions}

This study organized committees in order to evaluate the impact of the China-Korea FTA on industrial competitiveness and employment, and conducted a FuzzyDelphi survey of the panel of experts. The findings are as follows.

According to the results of the GTAP-CGE model on the impact of the China-Korea FTA on employment, the trade between the two countries will maintain a trend of rapid increase due to the rapid growth of the Chinese economy. Moreover, it is highly likely that the basic structure of competition and ripple effects by industry will continue for the time being. In manufacturing alone, the FTA with China will not only impact the Korean economy positively, but employment will increase as well in the manufacturing sector. For instance, in the FTA with China, employment is expected to increase by at least 140,000 new jobs and at most 220,000 new jobs.

The result of the Fuzzy-Delphi survey of the panel of experts on the impact of the China-Korea FTA on employment is as follows. In the industry as a whole, the FTA will be positive for both Korea and China in terms of employment. The industry that will benefit the most from the China-Korea FTA for both Korea and China in terms of employment is textile \& clothing. Industries that will be favorable to China, but unfavorable to Korea, are processed foods, mining, wood furniture, and agriculture, forestry, and fisheries. On the other hand, industries that will be favorable to Korea, but unfavorable to China, in employment are machinery, electric \& electronic goods, chemicals \& plastics, automobiles \& parts, petroleum \& coal products, other transportation equipment, steel, and other manufacturing. In particular, the industry that will be absolutely disadvantageous to Korea and therefore is politically infeasible to be opened is agriculture, forestry, and fisheries; however, for China, there is no particular industry that should not be opened in the perspective of employment.

In consideration of these results, a negotiation strategy must be prepared. For instance, the first goal of negotiations should be to reach an agreement on industries that will be favorable for both parties, and the second negotiation target should be to focus on areas favorable to Korea, but unfavorable to China or areas unfavorable to Korea, but favorable to China. For Korea, the labor market could experience a negative impact and the stability of labor-management relations could be harmed in the processing foods sector. Therefore, partial safeguards, extension of implementation period, and exclusion from the tariff removal list are required as responsive measures in the processed foods sector. The third target of negotiations is to pursue barter negotiations in industries that are very favorable for Korea, but unfavorable to China, and industries that are favorable for China, but unfavorable to Korea. In the case of Korea, the labor market can be negatively impacted in the industries of mining, wood furniture, and agriculture, forestry, and fisheries. In particular, for agriculture, forestry, and fisheries, a written provision of safeguard measures, exclusion from the tariff 
removal list, and the extension of the implementation period should be sought. As a return service, the demands of China for machinery, electrical \& electronic goods, chemicals \& plastics, and automobiles \& parts should be met during negotiations. The most difficult area to reach an agreement in is the sectors of agriculture, forestry, and fisheries. For this industry, in terms of employment, Korea is at an absolute disadvantage, whereas China seeks to gain absolute advantage.

The international experiences on the simulation and the actual outcome may be shared by forming a global community of scholars who intend to assess the FTA effects of the various countries. Connecting these results may enable us to assess the ripple effect on the world economy. For the Korean case, one may contact the corresponding author (Rhee) (rheehc@skku.edu) to share the experience of Korean FTA cases.
Overall, the China-Korea FTA will have a positive impact on the industrial competitiveness and employment in Korea; however, according to the results of negotiations with China, there will be inevitably a negative impact on industries and workers displaced by the trade adjustment. The readjustment strategy for workers impacted by the trade adjustment should be addressed in the perspective of labor-management relations rather than the perspective of industry. Key measures to stabilize labor-management relations include the economic resolution of labor conflicts and quick provision of information, strengthening of funding for the compensation of damages from the ChinaKorea FTA, real improvements in training programs, and the introduction of a contribution system for trade liberalization profits to be used as a source of funding for the compensation of damages caused by the China-Korea FTA.

\section{References}

Lashgari, A., Yazdani-Chamzini, A., Fouladgar, M. M., Zavadskas, E. K., Shafiee, S., \& Abbate, N. (2012). Equipment Selection Using Fuzzy Multi Criteria Decision Making Model: Key Study of Gole Gohar Iron Min. Inzinerine Ekonomika-Engineering Economics, 23(2), 125-136.

Baldwin, R. E. (2006). Multilateralising Regionalism: Spaghetti Bowls as Building Blocs on the Path to Global Free Trade. The World Economy 29(11), 1451-1518. http://dx.doi.org/10.1111/j.1467-9701.2006.00852.x

Cheong, I. (2006). Estimating Economic Impacts of a China-Korea FTA. Kukje Kyungje Yongu 12(1), 111-138 (Korean Language).

Cho, J. (2004). Flexibility, Instability and Institutional Insecurity in Korean Labor Market. Journal of Policy Modeling 26, 315-351. http://dx.doi.org/10.1016/j.jpolmod.2004.03.006

Cho, J. (2005) Human Resource Management, Corporate Governance Structure and Corporate Performance in Korea: a Comparative Analysis of Japan, US and Korea. Japan and the World Economy 17, 417-430. http://dx.doi.org/10.1016/j.japwor.2004.03.005

Cho, J., \& Cho, D. (2011). Gender Difference of the Informal Sector Wage Gap: a Longitudinal Analysis for the Korean Labor Market. Journal of the Asia Pacific Economy, 16(4), $612-629$. http://dx.doi.org/10.1080/13547860.2011.621363

Cho, J., \& Keum, J. (2004) Job Instability in the Korean Labour Market: Estimating the Effects of the 1997 Financial Crisis. International Labour Review 143, 373-392. http://dx.doi.org/10.1111/j.1564-913X.2004.tb00554.x

Cho, J., Taehee, K., \& Junki, A. (2010). Half Success, Half Failure in Korean Affirmative Action: An Empirical Evaluation on Corporate Progress. Women's Studies International Forum. 33, $264-273$. http://dx.doi.org/10.1016/j.wsif.2010.02.020

Cho, J., \& Kyu Young, L. (2007). Deregulation of dismissal law and unjust dismissal in Korea. International Review of Law and Economics 27, 409-422. http://dx.doi.org/10.1016/j.irle.2007.09.001

Cho, J., \& Sungwoong, K. (2005). On Using Mandatory Retirement to Reduce Workforce in Korea. International Economic Journal 19, 283-303. http://dx.doi.org/10.1080/10168730500080550

Cho, J., \& Iljoong, Kim. (2001). Jobs in the Bureaucratic Afterlife: A Corruption-Facilitating Mechanism Associated with Law Enforcement. Southern Economic Journal, 68, 330-348. http://dx.doi.org/10.2307/1061597

Cho, J., Scott C. L., \& Ashraf Nakibullah. (1996). Tax Evasion with Psychic Costs and Penalty Renegotiation. Southern Economic Journal, 63, 172-190. http://dx.doi.org/10.2307/1061312

Berzinskiene, D., \& Juozaitiene, L. (2011). Impact of Labour Market Measures on Unemployment. Inzinerine EkonomikaEngineering Economics, 22(2), 186-195.

Dubois, D., \& Prade, H. (1978). Operations on Fuzzy Number. International Journal of System Science, 9(6), 613-626. http://dx.doi.org/10.1080/00207727808941724

Hertel, T. W. (1997). Global Trade Analysis: Modeling and Applications. Cambridge University Press.

Keeney, R. L. (1992). Value-Focused Thinking: A Path to Creative Decision Making: MA Cambridge: Harvard University Press. 
Kooten, van., G. C., Krcmar, E., \& Bulte, E. H. (2001). Preference Uncertainty in Non-Market Valuation: A Fuzzy Approach. American Journal of Agricultural Economics, 83(3), 487-500. http://dx.doi.org/10.1111/00029092.00172

Lee, J. W., \& Park, I. (2005). Free Trade Areas in East Asia: Discriminatory or Non-discriminatory?. The World Economy 28(1), 21-48. http://dx.doi.org/10.1111/j.1467-9701.2005.00673.x

Lee, H., \& Park, I. (2007). In Search of Optimized Regional Trade Agreements and Applications to East Asia”, The World Economy 30(5), 783-806. http://dx.doi.org/10.1111/j.1467-9701.2007.01024.x

Low, L. (2003). Multilateralism, Regionalism, Bilateral and Crossregional Free Trade Arrangements: All Paved with Good Intentions for ASEAN?". Asian Economic Journal 17(1), 65-86. http://dx.doi.org/10.1111/1351-3958.00162

Moon, H. S., \& Lee. J. D. (2005). A Fuzzy Set Theory Approach to National Composite S\&T Indices. Scientometrics 64(1), 67-83. http://dx.doi.org/10.1007/s11192-005-0238-7

Rhee, H. C. (2007). Fuzzy Set Theory and Evaluation. Evaluation Review 6, 152-165 (Korean Language).

Rhee, H. C., Lee, K. Y., \& Lee, I. J. (2007). Fuzzy Set Theory As a Method of Policy Evaluation: With a Case of Job Creation Policy. Korean Policy Review 16(3), 67-92(Korean Language).

Saaty, T. L. (1994). Fundaments of Decision Making and Priority Theory with the Analytical Hierarchy Process. Pittsburgh: PA: RWS Publication.

Satty, T. L. (1996). Decision Making with Dependence and Feedback: the Analytic Network Process: the Organization and Prioritization of Complexity, Pittsburgh, PA: WS publication.

Razeen, S. (2006). Free Trade Agreements and the Prospects for Regional Integration in East Asia. Asian Economic Policy Review, 1(2), 306-321. http://dx.doi.org/10.1111/j.1748-3131.2006.00036.x

Soesastro, H. (2006). Regional Integration in East Asia: Achievements and Future Prospects. Asian Economic Policy Review, 1(2), 215-234. http://dx.doi.org/10.1111/j.1748-3131.2006.00024.x

The Korea International Trade Association, 2012. Data Base, www.kita.net.

Tongzon, J. L. (2005). ASEAN-China Free Trade Area: A Bane or Boon for ASEAN Countries?. The World Economy, 28(2), 191-210. http://dx.doi.org/10.1111/j.1467-9701.2005.00643.x

Tsaur, S. H., Chang, T. Y., \& Yen, C. H. (2002). The evaluation of airline service quality by fuzzy MCDM. Tourism Management, 23, 107-115. http://dx.doi.org/10.1016/S0261-5177(01)00050-4

Zadeh, L. A. (1965). Fuzzy Sets. Information and Control, 8, 338-353. http://dx.doi.org/10.1016/S00199958(65)90241-X

Cho Joonmo, Woo Kwangho, Rhee Hae-Chun

\section{Kinijos- Korèjos LPS ịdarbinimo ịtaka: derybų strategija ir institucinis pasiruošimas šalims, siekiančioms sudaryti LPS su Kinija}

Santrauka

Kinija yra ne tik viena iš didžiausių šalių, bet ir antra ekonomikos milžinė pasaulyje. Dèl šios priežasties, daugelis šaliu, besiruošiančių sudaryti LPS (Laisvos prekybos sutartis) su Kinija, įskaitant ES, išreiškia susirūpinimą dẻl vietinès pramonès smukimo, ypač dẻl darbo žemės ūkio pramonės srityse. Šis tyrimas empiriškai įvertina Kinijos-Korejos LPS įtaką abiejų šalių pramonès konkurencingumui ir darbo rinkai. Buvo atlikta Kinijos-Korėjos LPS itakos ekonometrinè analizė, o ekspertu grupei ištirti buvo atlikta Fuzzy-Delphi analizė, kad būtų papildyta kiekybinė analizė. Po to, i̇vertinant nuomones, buvo panaudotas Fuzzy sprendimu priemimo metodas. Norint îvertinti politiką, reikia ịvertinimo indekso, kuris būtų pagrindiniu įvertinimo rodikliu, apimančiu lingvistines išraiškas, kurias sunku paversti realiais indeksais. Šiuo atveju, vertintojo subjektyvumą ir netikslumą neišvengiamai atskleidžia ivertinimo indeksas. Fuzzy aibès teorija - tai metodas, kuris gali sistemiškai atskleisti žodžiu pasiūlytos ịvertinimo priemonès netikslumą. Metodas nagrinèja ekspertų grupès sprendimų netikslumus Delphi-stebejjime, kuris numato kokybinę Kinijos-Korèjos LPS įtaką. GTAP-CGE modelis, kuris buvo pasiūlytas pramonès ekspertams ir darbo komitetui kaip pagrindinè informacija, prognozuoja, kad abiejų šaliu BVP pagerės, sudarius LPS. Pagal ši scenarijų, Korèjos BVP padidès 3.1 5.0 \% . Tikimasi, kad BVP padidès daugiau, atsiradus didesniems rinkos atvėrimo požymiams. Kinijos nacionalinės pajamos, sudarius Kinijos-Korèjos LPS padidès, tačiau, tikimasi, kad didejjimo riba bus mažesnė nei Korẻjos. Tai, kad Kinijos BVP mažesnis už Korėjos, paaiškina pramonès ir prekybos struktūrų skirtumai. Tačiau, CGE modelio rezultatai turi keletą apribojimų, tokių kaip modeliavimo duomenų ir prognozavimo laiko momento problema, rimtų parametrų nejudamumas, apribojimai parodant restruktūrizavimo įtaką, taip pat netikslus įdarbinimo itakos ivertinimas. Šiame darbe atliekamas ekspertu grupès Delphi stebejjimas, norint papildyti GTAP CGE modelio rezultatus. Fuzzy metodo rezultatai yra tokie. Visos pramonès paprasto ịvertinimo rezultatas yra 3.36, o Fuzzy ịvertinimo rezultatas yra 3.12. Tai reiškia, kad Kinijos-Korèjos LPS bus palanki Korejos pramonės konkurencingumui esant didesniam nei vidutinis lygis. Norint nustatyti pramoninės produkcijos pirmenybę Korėjoje, pramonė buvo padalinta i penkias grupes. Pagal šiuos kriterijus, pramonės šakos, kurios turètų igyti didelių privalumų pramoninëje gamyboje dėl Kinijos-Korèjos LSP sudarymo, yra mašinų gamyba, elektros ir elektronikos prekès, bei chemikalai ir plastikai, po kurių eitų tekstile ir apranga, automobiliai ir jų dalys, naftos ir anglies produktai, tai pat plienas. Pramonès šakos, kurias tai nelabai palies būtų: kitokia gabenimo ịranga ir ne metaliniai mineraliniai produktai. Pramonės šakos, kurioms tai bus nenaudinga, yra metalo gaminiai, spalvotieji metalai, maisto pramonė ir mediniai baldai. O pramonės šakoms, kaip kalnakasyba, žemès ūkis, miškininkystè, žuvininkyste bus labai nenaudinga. Vertinant įdarbinimo Korejoje perspektyvą, visos pramonės, paprasto i̇vertinimo rezultatas yra 3.18, o Fuzzy įvertinimo rezultatas yra 3.01. Kinijos-Korejos LPS atveju įdarbinimo Korėjoje įvertinamas yra didesnis už vidutini, todèl jis bus tik šiek tiek palankesnis. Nustatant įdarbinimo Korejoje privalumų ir trūkumų lygi, pati palankiausia pramonės šaka (įdarbinimo Korèjoje požiūriu dèl Kinijos-Korejos LPS), yra mašinų gamyba, o naudingos pramonès šakos yra chemikalai ir plastikai, elektros ir elektronikos prekès bei automobiliai ir jų dalys. Vidutiniškai naudingos pramonės šakos yra naftos ir anglies produktai, plienas, kita gabenimo ịranga, tekstile bei apranga.

Iš kitos pusès, ekspertų grupès nuomonè apie pramoninės gamybos Kinijoje įtaką dèl Kinijos-Korejos LPS yra tokia. Kinijos-Korejos LPS bus naudinga Kinijai, nes jos įvertinimas yra didesnis už vidutinį. Didelis skirtumas tarp paprasto įvertinimo ir Fuzzy įvertinimo rodo, kad įvertintojų nuomonès labai skyrèsi vertinant pramonini konkurencingumą. Kitaip tariant, lyginant su gautais duomenimis apie Koréjos pramoninio konkurencingumo įvertinimą, vertinimui trūko duomenų, kad būtų galima ịvertinti pramoninę gamybą Kinijoje. Lyginant pramonès šakas, pačios 
Joonmo Cho, Kwangho Woo, Hae-Chun Rhee. Industrial and Employment Effect of China-Korea FTA: Negotiation...

naudingiausios yra žemės ūkis, miškininkystė ir žuvininkystė, tekstilè ir apranga, bei medžio baldai. Ekspertai buvo ỉsitikinę teisumu dèl savo sprendimo apie šias pramonès šakas. Ypač užtikrinti buvo dẻl įvertinimo žemès ūkiui, miškininkystei ir žuvininkystei, kurie yra patys naudingiausi, turẻdami gana aukštą îvertinimą, lygu 4.45. Po jų naudinga pramonės šaka yra kalnakasyba. Pramonės šaka, kurią nelabai paveikia, yra maisto pramonė, o nenaudingos pramonės šakos yra visos kitos: kita gabenimo ịranga, kita gamyba, automobiliai ir jų dalys, plienas, naftos ir anglies produktai, spalvotieji metalai, metalo gaminiai, elektros ir elektronikos prekès, nemetaliniai mineraliniai produktai, chemikalai ir plastikai, bei mašinų gamyba. Kinijos atveju, nėra tokiu pramonės šakų, kurios būtų visiškai nenaudingos pramoninio konkurencingumo požiūriu dėl Kinijos-Korèjos LSP. Kinijos-Korėjos LPS itaka i̇darbinimui Kinijoje yra tokia: Kinijos-Korejos LPS įdarbinimą visoje Kinijos pramonèje nelabai paveiks. Atitinkamai, ekspertu grupés sprendimas dėl Fuzzy îvertinimo įtakos įdarbinimui Kinijoje, yra mažesnis už Korejos tokị pat įvertinimą. Vadinasi vertintojams iš dalies trūko informacijos, kad jie galètų pateikti išvadas dèl Kinijos-Korèjos LPS daromos įtakos įdarbinimui Kinijoje, lyginant su Korèja. Tiksliau tariant, optimistinis požiūris, kad įdarbinimas Kinijoje bus didesnis dèl Kinijos-Korèjos LPS, prieštarauja pesimistiniam požiūriui, kad įdarbinimas nedidès.Tai reikštų, kad KinijosKorejos LPS įdarbinimui Kinijoje teigiamos įtakos gali ir nedaryti. Nagrinejjant ir aptariant šiuos rezultatus, turi būti numatyta derybu strategija. Pirmasis derybų tikslas turètų būti tai, kad būtų pasiektas susitarimas dẻl tų pramonės šakų, kurios bus naudingos abiems šalims, o antrasis derybų tikslas turètų būti toks: dèmesys sutelktas ị sritis, naudingas Korèjai, bet nenaudingas Kinijai, arba sritis nenaudingas Korèjai, bet naudingas Kinijai. Korèjoje darbo rinka gali patirti neigiamą ittaką. Darbo valdymo stabilumo santykiai gali būti pažeisti maisto pramonès sektoriuje. Todėl, maisto pramonės sektoriuje, kaip atsakomosios priemonès turi būti numatytos dalinės apsaugos priemonès: įdiegimo periodo pratęsimas ir išbraukimas iš tarifo nurašymo sąrašo. Trečiasis derybų tikslas, yra siekti derybų dèl mainų pramonės šakose, kurios yra pačios naudingiausios Korèjai, bet nenaudingos Kinijai, ir pramonės šakose, kurios yra naudingos Kinijai, bet nenaudingos Korejjai. Korèjos atveju darbo rinka gali būti neigiamai paveikta kalnakasybos, medžio baldų, žemès ūkio, miškininkystès ir žuvininkystès šakose. Ypač žemès ūkyje, miškininkystès ir žuvininkystės srityse turètų būti siekiama apsaugos priemonių raštu, i̇diegimo laikotarpio pratęsimo. Mainais derybų metu turètų būti patenkinti Kinijos reikalavimai mašinų gamybai, elektros ir elektronikos prekėms, chemikalams ir plastikams bei automobiliams ir jų dalims. Sritis, kurioje sudėtingiausia pasiekti susitarimą, yra žemės ūkis, miškininkystė ir žuvininkystė. Šiai pramonei, įdarbinimo požiūriu, Korèja patiria visišką nuostolị, kai tuo metu Kinija gauna naudą.

Apibendrinant reiktų pasakyti, kad modeliuojamų ir tikrų tyrimų rezultatų tarptautinę patirti galima pasidalinti formuojant globalią mokslininkų, kurie nori ịvertinti îvairių šalių LPS įtaką, bendruomenę. Šių rezultatų sujungimas ir ivvertinimas leistų mums suprasti naudą ar žalą pasaulinei ekonomikai. Apskritai tariant, Kinijos-Korejjos LPS turės teigiamą itaką pramoniniam konkurencingumui ir įdarbinimui Korėjoje, tačiau, anot derybų su Kinija rezultatu, bus neišvengiama neigiama įtaka pramonès šakoms ir darbininkams, kuriuos išstums prekybos kaita. Pertvarkymo strategija darbininkams, kuriuos palies prekybos pertvarkymas, turètų būti labiau nukreipta i darbo valdymo santykių perspektyvą, nei i pramonės perspektyvą. Pagrindinès priemonès stabilizuoti darbo valdymo santykius susijusi su ekonominiu darbo konfliktų sprendimu ir greitu informacijos pateikimu, finansavimo stiprinimu kompensuojant žalą dėl Kinijos-Korèjos LPS, realiu mokymo programų tobulinimu ir i̇mokų sistema, kad prekybos liberalizavimo pelnas būtų naudojamas kaip finansavimo šaltinis Kinijos-Korèjos LSP sukeltai žalai kompensuoti.

Raktažodžiai: Kinijos-Korejos LPS, darbo rinkos itaka, pramoninis konkurencingumas, Delphi, Fuzzy metodas.

The article has been reviewed.

Received in November, 2012; accepted in April, 2013. 